\title{
Ontogenetic shift in the trophic role of the invasive killer shrimp Dikerogammarus villosus: a stable isotope study
}

\author{
Francesco Mancini • Raffaele De Giorgi · Alessandro Ludovisi • \\ Salvatrice Vizzini • Giorgio Mancinelli $($ )
}

Received: 21 April 2020/Accepted: 31 January 2021/Published online: 19 February 2021

(C) The Author(s) 2021

\begin{abstract}
The introduction of the amphipod Dikerogammarus villosus in European fresh waters is to date recognized as a threat to the integrity of invaded communities. Predation by $D$. villosus on native benthic invertebrates is assumed as the key determinant of its ecological impact, yet available information describe the species as a primary consumer as well as a carnivore depending on local conditions. Here, we assessed the trophic position (TP) of $D$. villosus in Lake Trasimeno, a recently invaded lentic system in central Italy, using the $\mathrm{CN}$ isotopic signatures of individuals captured in winter spanning two orders of magnitude in body size. TP estimations were compared with those characterizing the native amphipod Echinogammarus veneris and other
\end{abstract}

Supplementary information The online version of this article (https://doi.org/10.1007/s10530-021-02472-0)

F. Mancini · R. De Giorgi · G. Mancinelli ( $₫)$

Department of Biological and Environmental Sciences and Technologies, University of Salento, 73100 Lecce, Italy

e-mail: giorgio.mancinelli@unisalento.it

\section{A. Ludovisi}

Department of Chemistry, Biology and Biotechnologies, University of Perugia, 06123 Perugia, Italy

\section{S. Vizzini}

Department of Earth and Marine Sciences, University of Palermo, 90123 Palermo, Italy representative invertebrate predators. On average, $D$. villosus showed a trophic position higher than $E$. veneris, and comparable with that of odonate nymphs. An in-depth analysis revealed that large-sized individuals had a trophic position of 3.07, higher than odonates and close to that of the hirudinean predator Erpobdella octoculata, while small-sized specimens had a trophic position of 2.57 , similar to that of $E$. veneris (2.41). These findings indicate that sizerelated ontogenetic shifts in dietary habits may per se vary the nature of the interaction between Dikerogammarus villosus and native invertebrates from competition to predation. Information collated from published isotopic studies corroborated the generality of our results. We conclude that intraspecific trophic flexibility may potentially amplify and make more multifaceted the impact of the species on other invertebrate species in invaded food webs.

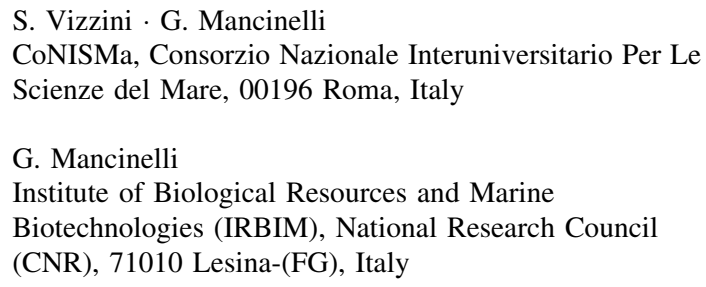


Keywords Killer shrimp - Trophic position ·

Stable isotopes · Ontogeny $\cdot$ Body size

\section{Introduction}

The introduction of aquatic non-indigenous species has long been recognized to have important, disruptive consequences for the structure and function of freshwater ecosystems (Elton 1958; Dudgeon et al. 2006; Gherardi 2007; Strayer 2010; Gallardo et al. 2016; Emery-Butcher et al. 2020). Among other invertebrates introduced in European waters, the killer shrimp Dikerogammarus villosus (Sowinsky 1894), a gammarid amphipod of Ponto-Caspian origin, after the opening of the Rhine-Main-Danube Canal has established in German rivers including the Danube, Moselle, and Rhine (Bij de Vaate et al. 2002). Subsequently, the species spread in lentic and lotic environments in France, the Netherlands, Great Britain, and Switzerland (Devin et al. 2001; van der Velde et al. 2002; Koester and Gergs 2014; MacNeil et al. 2010; Rewicz et al. 2017), as well as towards the Baltic region (Bącela et al. 2008; Gusev et al. 2017 and literature cited). In Italy, the killer shrimp appeared in Lake Garda in 2003 (Casellato et al. 2006) and subsequently invaded the northern and central regions of the peninsula (Tricarico et al. 2010).

The predatory behavior of the killer shrimp is generally recognized as a crucial determinant of its ecological impact on other benthic invertebrates, including native amphipods. A number of laboratory trials on the feeding preferences of the gammarid supports this assumption (Krisp and Maier 2005; Kinzler et al. 2008; Pellan et al. 2016; Taylor and Dunn 2017), together with indirect evidences from field investigations highlighting significant declines in native macroinvertebrate assemblages after $D$. villosus invasion (Muskó 1989; Bollache et al. 2004; Noordhuis et al. 2009).

Noticeably, information on the actual impact of the gammarid on benthic communities are less univocal (Hellmann et al. 2017; Koester et al. 2018). In addition, field studies using carbon and nitrogen stable isotopes analysis (SIA hereafter), have emphasized a high variability in dietary habits, with trophic position estimations varying by more than one trophic level from a maximum of 3.7 in the Vistula basin
(Poland) to a minimum of 2.1 in the River Arno (Italy) (Bacela-Spychalska and Van Der Velde 2013; Haubrock et al. 2019).

Indeed, D. villosus shows no morphological specialization of the mouthparts for a carnivorous diet (Mayer et al. 2008), and it has been repeatedly indicated to be an omnivore in invaded food webs feeding opportunistically also on vegetal resources (Maazouzi et al. 2007; Truhlar et al. 2014; Boeker and Geist 2015; Jourdan et al. 2016). Accordingly, the species is generally posited to adapt its trophic habits to local environmental conditions, switching between different functional feeding groups depending on season, habitat, and resource availability (Maazouzi et al. 2009; Pellan et al. 2016; Hellmann et al. 2017). Noticeably, Hellmann and colleagues (2015) indicated that the trophic position of $D$. villosus can vary not only among different locations, but also among different ontogenetic stages within the same population, in turn suggesting that the species may play simultaneously multiple functional roles within an invaded food web. So far this aspect of the killer shrimp trophic ecology has generally received scant attention in field studies, even though ontogenetic diet shifts seem to represent a common trophic trait in invasive aquatic species, from crustaceans (Limén et al. 2005; Berezina 2007; Mancinelli et al. 2016; 2017b) to fish (Števove and Kováč 2016; Lee et al. 2018). Accordingly, here we verified whether Dikerogammarus villosus is characterized by a high feeding plasticity at the intra-population level related with a size/ontogenetic shift in trophic habits. The alternative hypothesis was that the species maintains constant trophic habits independently from size and ontogenetic stage (as observed for e.g., Gammarus pulex: Dick et al. 2013). The trophic position of the killer shrimp was assessed in Lake Trasimeno, a recently invaded lentic system in central Italy (Catasti et al. 2017) using stable carbon and nitrogen isotope analysis. To test the hypothesis, we determined the $\mathrm{CN}$ isotopic values in $D$. villosus specimens spanning two orders of magnitude in individual size and assessed the trophic position of different ontogenetic stages of the species using a Bayesian procedure. Estimations were eventually compared with the trophic position characterizing the native amphipod Echinogammarus veneris and other representative invertebrate predators. 
Since the present investigation focused only on a single population of the killer shrimp sampled in a single season, to verify the generality of our results we reviewed the isotopic literature focusing on the trophic position of $D$. villosus, making an effort to collate information from studies explicitly addressing ontogenetic shifts. In the last decades, SIA has gained popularity as a powerful complement to the study of food webs and of the factors affecting their structure and dynamics (including biological invasions: see Mancinelli and Vizzini 2015; McCue et al. 2020 for recent reviews), allowing robust, large-scale comparisons of species' dietary habits in space and time (e.g., Mancinelli 2012a; Pethybridge et al. 2018; Evangelista et al. 2019; Lang et al. 2020; Liénart et al. in press).

\section{Methods}

Study site and samples collection

The study was carried out in Lake Trasimeno (Central Italy), the largest lake in the Italian Peninsula, with a surface area of $128 \mathrm{~km}^{2}$ and an average depth of $4.7 \mathrm{~m}$. Further details on lake features can be found in Ludovisi and Gaino (2010) and in Mancinelli et al. (2018). The basin is included in a Regional Natural Park comprised in the Natura 2000 European network as a Site of Community Interest (SCI) and a Special Protection Area (SPA). The macroinvertebrate community of the lake littorals is characterized by a diverse assemblage of epibenthic taxa, including herbivorous/detritivorous crustaceans (e.g., the amphipod Echinogammarus veneris, the isopod Asellus coxalis, and the decapod Palaemonetes antennarius) and gastropods (e.g., Valvata piscinalis, Bithynia tentaculata, and B. leachii), together with predaceous insects (e.g., the coleopterans Gyrinus caspius, $G$. substriatus, and odonate nymphs of the genera Ashna, Coenagrion, Erythromma, Ischnura, and Lestes) and hirudineans (e.g., Erpobdella octoculata, Helobdella stagnalis, and Hirudo medicinalis) (Minelli 1979; VV.AA. 2015; Mancinelli et al. 2020).

Noticeably, during the last century the native lacustrine community has been drastically altered by the introduction of a number of non-indigenous species of different origin, including invertebrates (e.g., Procambarus clarkii, Dreissena polymorpha, and Sinanodonta woodiana) and fish (e.g., Lepomis gibbosus, Ictalurus melas, Carassius auratus, and Pseudorabora parva) (Dörr et al. 2020; Goretti et al. 2020; Lorenzoni et al. 2020). The killer shrimp appeared in the lake in 2017 (Catasti et al. 2017), and breeding populations are to date established in several areas of the basin (VV.AA. 2020).

In February 2018, invertebrates were collected using a pond net (mesh size $=1 \mathrm{~mm}$ ) from rocks and floating leaf detritus accumulations in a shallow embayment (approximate depth $=1 \mathrm{~m}$ ) in the locality of Sant'Arcangelo in the southern sector of the lake $\left(43.089788^{\circ} \mathrm{N}, 12.156246^{\circ} \mathrm{E}\right)$. After collection, samples were transferred to the laboratory in lake water using refrigerated containers $\left(4^{\circ} \mathrm{C}\right)$.

\section{Laboratory procedures}

In the laboratory, collected specimens were individually identified under a light microscope to the lowest taxonomic level. Immediate identification after collection, when the natural coloration of amphipods was still maintained, allowed a relatively easy differentiation of Dikerogammarus villosus specimens, characterized by a striped morph in Lake Trasimeno (VV.AA. 2020), from the native Echinogammarus veneris, showing a uniform coloration. Given the high color polymorphism of the killer shrimp (see e.g., Devin et al. 2004a for illustrative examples), an additional trait used for the identification of $D$. villosus was the occurrence of dorsal projections on the $1^{\circ}$ and $2^{\circ}$ urosome segments, absent in E. veneris (Stock 1968; Eggers and Martens 2001; Konopacka 2004). Individuals of the six identified species (see Results) were kept in distilled water for $12 \mathrm{~h}$ to clear gut contents and euthanized by thermal shock $\left(-80^{\circ} \mathrm{C}\right.$ for $10 \mathrm{~min})$.

\section{Stable isotope analysis}

After being euthanized, specimens were oven-dried $\left(60{ }^{\circ} \mathrm{C}\right.$ for at least 1 week), and individually weighed to the nearest $\mu \mathrm{g}$ using a micro-analytical balance. Consequently, specimens were individually powdered with a mortar and pestle. Depending on the taxon, subsamples of different sizes were taken (amphipods: $0.73 \pm 0.19 \mathrm{mg}$; isopods: $0.18 \pm 0.02 \mathrm{mg}$; odonate nymphs: $0.61 \pm 0.03 \mathrm{mg}$; hirudineans: $0.79 \pm 0.01$, means $\pm 1 \mathrm{SD}$ ) and pressed into Ultra-Pure tin 
capsules (Costech Analytical Technologies). For amphipods, multiple specimens with dry weight identical to the first decimal place were pooled when single individuals did not provide a sufficient mass. Carbon and nitrogen stable isotope values were determined using an Elemental Analyser (Thermo Scientific Flash EA 1112) connected with an Isotope Ratio Mass Spectrometer (Thermo Scientific Delta Plus XP). Isotopic values were expressed in conventional $\delta$ notation (as \%o) in relation to international standards (Pee Dee Belemnite for carbon and atmospheric $\mathrm{N}_{2}$ for nitrogen). Analytical precision based on the standard deviation of replicates of standards (International Atomic Energy Agency IAEA-NO-3 for $\delta^{15} \mathrm{~N}$ and IAEA-CH- 6 for $\delta^{13} \mathrm{C}$ ) was $0.1 \%$ for both $\delta^{13} \mathrm{C}$ and $\delta^{15} \mathrm{~N}$. Invertebrate taxa showed variable $\mathrm{C}: \mathrm{N}$ ratios, in some cases $>3.5$ (see Tab. 1 in results) thus indicating a non-negligible contribution of lipids to tissue carbon pool (Post et al. 2007). Lipids are depleted in ${ }^{13} \mathrm{C}$ compared to proteins and carbohydrates and can significantly bias $\delta^{13} \mathrm{C}$ estimations (Logan et al. 2008). Accordingly, for samples with a $\mathrm{C}: \mathrm{N}$ ratio $>3.5, \delta^{13} \mathrm{C}$ values were corrected for lipid content using tissue $\mathrm{C}: \mathrm{N}$ ratios following the algorithm proposed by Post et al. (2007). Lipid-corrected $\delta^{13} \mathrm{C}$ values were used in further analyses.

\section{Literature search}

Isotopic studies reporting on the killer shrimp were searched using the online databases ISI Web of Science, Scopus, and JSTOR (last access date: November 20th, 2020). We adopted a multiple search criterion, using the terms "Dikerogammarus villosus" or "killer shrimp" in combination with "stable isotopes" to search in all available fields. Additional information were found by checking the references of collected papers, and performing general searches in Google Scholar. The papers identified in the search (13 in total) were screened by a three-step approach using a title/abstract/full text procedure (Mancinelli et al. 2017a and literature cited therein). In order to be selected, publications had to (1) be performed in the field; laboratory studies were omitted, although they had their references scrutinized; (2) analyze the stable isotopes at least of nitrogen and (3) include an estimation of the trophic position of D. villosus or, alternatively, its nitrogen isotopic signature together with those of taxa located at the first or second trophic level. Data were extracted from tables and figures of 10 studies meeting the criteria; figures were digitized after a five-fold enlargement and converted to numerical format (estimated error: $0.02 \%$ ) using the

Table 1 List of sampled taxa reported in order of abundance

\begin{tabular}{|c|c|c|c|c|c|c|}
\hline Species & Order & $\mathrm{N}$ & Dry weight & $\delta^{13} \mathrm{C}$ & $\delta^{15} \mathrm{~N}$ & $\mathrm{C}: \mathrm{N}$ \\
\hline Dikerogammarus villosus & Amphipoda & 169 & $\begin{array}{l}9.1 \pm 15 \\
(0.4 / 27.7)\end{array}$ & $\begin{array}{c}-16.2 \pm 2.3 \\
(-19.1 /-13.6)\end{array}$ & $\begin{array}{l}7 \pm 2.1 \\
(4.7 / 9.4)\end{array}$ & $\begin{array}{l}5 \pm 0.8 \\
(4.3 / 5.9)\end{array}$ \\
\hline Erythromma sp. & Odonata & 12 & $\begin{array}{l}5.6 \pm 1.5 \\
(3.4 / 8)\end{array}$ & $\begin{array}{c}-17.6 \pm 0.8 \\
(-18.5 /-15.7)\end{array}$ & $\begin{array}{l}7.2 \pm 8.8 \\
(7 / 7.4)\end{array}$ & $\begin{array}{l}3.9 \pm 2.3 \\
(3.6 / 4.2)\end{array}$ \\
\hline Echinogammarus veneris & Amphipoda & 6 & $\begin{array}{l}3.8 \pm 2.4 \\
(1.6 / 7.7)\end{array}$ & $\begin{array}{l}-18.5 \pm 0.6 \\
(-19 /-17.5)\end{array}$ & $\begin{array}{l}5.3 \pm 1 \\
(4.2 / 6.3)\end{array}$ & $\begin{array}{l}6.4 \pm 0.8 \\
(5.7 / 8)\end{array}$ \\
\hline Asellus aquaticus & Isopoda & 5 & $\begin{array}{l}1.5 \pm 0.7 \\
(0.6 / 2.4)\end{array}$ & $\begin{array}{c}-18.5 \pm 1.4 \\
(-19.9 /-16.3)\end{array}$ & $\begin{array}{l}5.1 \pm 0.8 \\
(4.5 / 6.5)\end{array}$ & $\begin{array}{l}5.2 \pm 0.7 \\
(4.2 / 5.9)\end{array}$ \\
\hline Ischnura sp. & Odonata & 4 & $\begin{array}{l}3 \pm 0.4 \\
(2.7 / 3.6)\end{array}$ & $\begin{array}{c}-17.4 \pm 0.2 \\
(-17.6 /-17.2)\end{array}$ & $\begin{array}{l}7.4 \pm 0.4 \\
(6.8 / 7.8)\end{array}$ & $\begin{array}{l}3.8 \pm 0.1 \\
(3.6 / 3.9)\end{array}$ \\
\hline Erpobdella octoculata & Arhynchobdellida & 3 & $\begin{array}{l}7.3 \pm 3.5 \\
(3.3 / 9.8)\end{array}$ & $\begin{array}{c}-20.6 \pm 0.2 \\
(-20.8 /-20.5)\end{array}$ & $\begin{array}{l}11.5 \pm 0.8 \\
(10.7 / 12.2)\end{array}$ & $\begin{array}{l}4.3 \pm 0.2 \\
(4.1 / 4.5)\end{array}$ \\
\hline
\end{tabular}

Additional information on individual dry weights (in $\mathrm{mg}$ ), carbon and nitrogen isotopic values (in \%o), and C:N ratios are included as mean $\pm \mathrm{SD}$, with min-max values in parentheses. $\delta^{13} \mathrm{C}$ values were corrected considering $\mathrm{C}: \mathrm{N}$ ratios (see text for details). $\delta^{13} \mathrm{C}$, $\delta^{15} \mathrm{~N}$, and C:N values were determined in the totality of sampled individuals for all taxa with the exception of Dikerogammarus villosus, for which $\mathrm{CN}$ isotopic and elemental concentrations were determined in a subsample of 54 individuals whose individual dry weight ranged between 0.4 and $27.6 \mathrm{mg}$ 
freeware WebPlotDigitizer (ver. 4.3; https:// automeris.io/WebPlotDigitizer/).

The majority of the studies explicitly reporting $D$. villosus trophic position (see Results) used the equation $\mathrm{TP}=\left(\delta^{15} \mathrm{~N}_{\text {consumer }}-\delta^{15} \mathrm{~N}_{\text {baseline }}\right) / \Delta^{15} \mathrm{~N}+\lambda$ (Vander Zanden and Rasmussen 1999), where $\delta^{15-}$ $\mathrm{N}_{\text {consumer }}$ is the nitrogen isotopic signature of the killer shrimp, $\delta^{15} \mathrm{~N}_{\text {baseline }}$ and $\lambda$ are the nitrogen isotopic signature and the trophic position of a baseline taxon, while $\Delta^{15} \mathrm{~N}$ is the trophic level fractionation of $\delta^{15} \mathrm{~N}$ (3.4\%o: Post 2002). For the sake of comparison, we adopted the same formula and $\Delta^{15} \mathrm{~N}$ for those studies where the trophic position of $D$. villosus was not explicitly calculated using the isotopic signatures of the killer shrimp ( $\left.\delta^{15} \mathrm{~N}_{\text {consumer }}\right)$ and those of taxa with $\lambda=1$ or $2\left(\delta^{15} \mathrm{~N}_{\text {baseline }}\right)$.

Data analysis

In general, values reported in the paper are expressed as means $\pm 1 \mathrm{SD}$ if not otherwise specified. For parametric statistical analysis, data were tested for conformity to assumptions of variance homogeneity (Cochran's C test) and normality (Shapiro-Wilks test) and transformed when required. A Shapiro-Wilks test was also used to verify the normality of the size frequency distribution of collected $D$. villosus specimens. One-way Permutational Analysis of Variance (PERMANOVA: Anderson 2005) was run on a Euclidean distance matrix calculated on individual CN isotopic signatures with 9999 permutations of residuals within a reduced model to test for dissimilarities in isotopic values among taxa. PERMANOVA was also used to confirm the significance of the differences between size groups after a preliminary cluster analysis with complete linkage performed on the Euclidean distance matrix indicated a discontinuity in the isotopic signatures of the specimens analyzed (see Results).

The trophic positions of gammarids, odonate nymphs and hirudineans were estimated implementing a one-baseline, two-discrimination factor Bayesian model run with 2 parallel chains and 40,000 adaptive iterations, using the isopod Asellus aquaticus as isotopic baseline (see also Annabi et al. 2018 for an example). The species, together with the confamiliar Proasellus coxalis, is an herbivorous/detritivorous consumer widely distributed in Italian lentic and lotic waters and plays a significant role in leaf detritus processing in lacustrine environments (Marcus et al. 1978; Costantini et al. 2005). Accordingly, a trophic level $(\lambda)=2$ was assigned to A. aquaticus, assuming $\lambda=1$ for basal resources, $\lambda=2$ for primary consumers, etc., with the trophic enrichment factors (TEF hereafter) $\quad \Delta^{13} \mathrm{C}=0.57 \pm 1.58 \%$ and $\Delta^{15}$ $\mathrm{N}=3.40 \pm 1.04 \%$ (Post 2002). Even though a species-specific TEF measurement is available from the literature (i.e., Hellmann et al. 2015), here we used a general TEF value to make more comparable the trophic positions estimated for the different taxa analyzed in the study, as well as those collated for D. villosus from the literature.

All statistical analyses were performed in the $\mathrm{R}$ statistical environment (R Development Core Team 2020). Specifically, PERMANOVA was run in the package vegan (version 2.5-6; Oksanen et al. 2019), while trophic positions were estimated using the tRophicPosition package (version 0.7.7; QuezadaRomegialli et al. 2018; 2019). The function "compareTwoDistributions" available in the aforementioned package was used to statistically compare in a Bayesian context TP values estimated for the different taxa and size groups.

\section{Results}

Six taxa were captured in total, including the gammarid amphipods Dikerogammarus villosus and Echinogammarus veneris, the isopod Asellus aquaticus, odonate larval stages, and the hirudinean Erpobdella octoculata (Table 1). Only six and five adult specimens of A. aquaticus and of E. veneris were respectively collected, while $D$. villosus dominated in abundance with 169 individuals varying in size by two orders of magnitude (Table 1; see also Fig. S1 in the online material). Among predators, 16 odonate nymphs were captured belonging to the genus Erythromma and, to a minor extent, Ischnura (four specimens). In addition, three individuals of the hirudinean Erpobdella octoculata were collected (Table 1).

On average, Dikerogammarus showed $\delta^{15} \mathrm{~N}$ values lower by $4.5 \%$ than E. octoculata, but close to the overall isotopic values of odonate nymphs (Table 1). Ischnura individuals were significantly smaller than Erythromma (Table 1; t-test for separate variance estimates: $\quad \mathrm{t}=5.28, \quad P=0.0001, \quad$ adjusted 

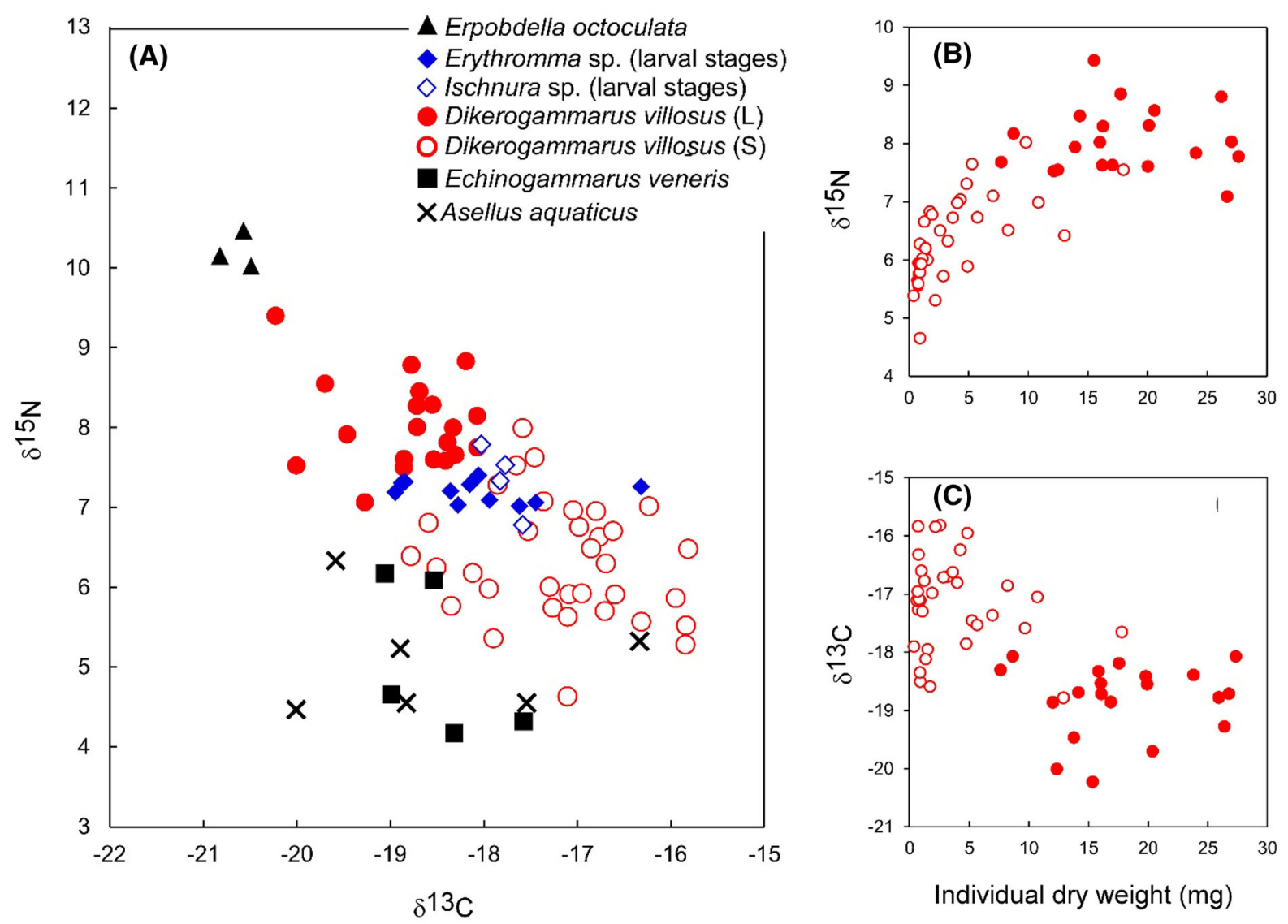

Fig. 1 (A) Bi-plot of individual $\delta^{13} \mathrm{C}$ and $\delta^{15} \mathrm{~N}$ values of the amphipods Dikerogammarus villosus and Echinogammarus veneris, Odonata larval stages, and the hirudinean Erpobdella octoculata. See Table 1 for summary statistics. For D. villosus, full and empty circles identify large-sized (L) and small-sized

d.f. $=13.91) ;$ nonetheless, negligible differences between the two taxa were verified in terms of isotopic values [1-way PERMANOVA on $\delta^{13} \mathrm{C}$ and $\delta^{15} \mathrm{~N}$ values, factor "taxon": Pseudo-F $=0.42, P($ perms $)=$ 0.42 , d.f. $=1.14]$. Accordingly, no distinctions were made between the two taxa in subsequent analyses.

$\delta^{13} \mathrm{C}$ and $\delta^{15} \mathrm{~N}$ values in individual $D$. villosus varied considerably (Table 1), suggesting a significant trophic plasticity. In particular, $\delta^{15} \mathrm{~N}$ varied by more than $4.5 \%$, shifting from values close to $E$. octoculata, to signatures comparable with those of A. aquaticus (Fig. 1A). In addition, $\delta^{15} \mathrm{~N}$ values showed a nonlinear increase with amphipod body size (Fig. 1B), while $\delta^{13} \mathrm{C}$ varied considerably, with small-size gammarids being more ${ }^{13} \mathrm{C}$-enriched compared with largesize individuals (Fig. 1C).
(S) individuals included in the two size groups recognized by cluster analysis and PERMANOVA (see Fig. S2 in the online information). The relationships between the individual dry weight of $D$. villosus specimens and the respective $\delta^{15} \mathrm{~N}$ (insert B) and $\delta^{13} \mathrm{C}$ values (insert $\mathbf{C}$ ) are also reported

A cluster analysis followed by a PERMANOVA revealed two distinct groups of $D$. villosus individuals with statistically different isotopic values (see Fig. S2 in supplementary online material). The first group included small-sized specimens with an individual dry weight of $3.78 \pm 0.69 \mathrm{mg}$ (range $0.39-17.98 \mathrm{mg}$ ); the second comprised large-sized gammarids with an average dry weight of $18.03 \pm 1.33 \mathrm{mg}$ (range 7.74-27.65 mg). Accordingly, the two size groups showed significantly different trophic positions ( $P=0.03$; Fig. 2). In particular, small-sized D. villosus showed a TP value not statistically different from that estimated for E. veneris $(2.57 \pm 0.14$ vs. $2.41 \pm 0.19 ; P=0.19$; mean $\pm 1 \mathrm{SD}$; see also Tab. $\mathrm{S} 1$ for additional statistical information on the robustness of the estimations). Conversely, large-sized killer 


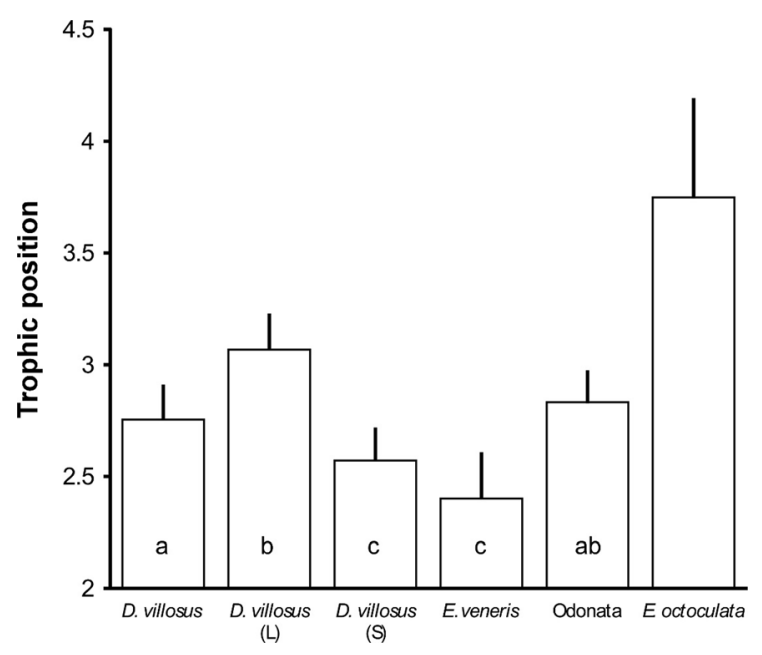

Fig. 2 Trophic positions (TP) of the amphipods Dikerogammarus villosus and Echinogammarus veneris, Odonata larval stages, and the hirudinean Erpobdella octoculata. For. D. villosus, TP values for large-sized (L) and small-sized (S) individuals included in the two groups differing significantly in their isotopic values after cluster analysis and PERMANOVA (see Fig. S2 in the online information) are also reported. Bars showing identical letters were not statistically different $(\alpha$ level $=0.05$ )

shrimps showed a TP of $3.07 \pm 0.15$, similar to the trophic position of odonate nymphs $(2.83 \pm 0.14$; $P=0.12$ ), but significantly lower than that of $E$. octoculata $(3.75 \pm 0.44 ; P=0.03)$.

The literature search and the subsequent selection procedure identified ten isotopic studies on D. villosus published between 2006 and 2019 (Tab. 2), including information on its trophic position either directly or providing $\delta^{15} \mathrm{~N}$ values for the killer shrimp and baseline taxa ( 5 studies per category). All the publications providing trophic position estimations used the equation by Vander Zanden and Rasmussen (1999) with the exception of Haubrock et al. (2019), where a Bayesian approach identical to the one adopted in the present study was used. The study by Haubrock and colleagues was also the only carried out in southern Europe (i.e., in the River Arno, Central Italy) while the remaining were all located in lakes and rivers of central European countries (Germany, the Netherlands, Poland, Switzerland, and Austria). 9 literature sources provided a total of 25 trophic position values estimated on bulk samples (Table 2A), corresponding to a mean TP of 2.38 ( $\pm 0.71 \mathrm{SD})$, but varying threefold between 1.7 and 4.9 independently from the system (i.e., river or lake: t-test for separate variance estimates: $\mathrm{t}=-0.52, P=0.61$, adjusted d.f. $=13.45$ ) or the season [1-way ANOVA, factor "season" with three levels ("spring"; "summer", and "autumn"): $\mathrm{F}_{2,21}=0.05, P=0.94$ after excluding the TP value from Bacela-Spychalska and van der Velde (2013), providing no indication of the sampling season].

Only three studies performed in Germany and the Netherlands estimated the trophic position of $D$. villosus considering the ontogeny of analyzed individuals (i.e., adult vs. juvenile; Table 2B). Over the 13 investigated locations the two developmental stages of the killer shrimp showed a two-fold variation in trophic position (Table 2B; adults min-max range: 1.9-3.5; juveniles: 1.5-3.3), yet adult D. villosus were generally characterized by TP values significantly higher than juveniles $(2.36 \pm 0.45$ vs. $2.14 \pm 0.49$, mean $\pm \mathrm{SD}$; t-test for paired samples: $\mathrm{t}=5.65$, $\mathrm{P}=0.0001,12$ d.f.).

\section{Discussion}

The results of the present study suggest that the individuals of a single population of Dikerogammarus villosus simultaneously play, depending on body size, two distinct functional roles within an invaded food web, shifting from omnivorous feeding habits that are predominantly plant-based and similar to the native amphipod Echinogammarus veneris, to a markedly predaceous strategy comparable with those characterizing odonate nymphs.

Dikerogammarus villosus showed a bipartite pattern in the isotopic signatures of its specimens (Fig. 1, and Fig. S1), and, in turn, a dual trophic position (Fig. 2). These findings corroborate and extend the results of other studies where the effect of size on the isotopic values of $D$. villosus has been addressed explicitly (see references in Tab. 2B). In particular, Koester and colleagues (2016) found in the majority of ten populations of $D$. villosus analyzed in the River Rhine a size-related positive shift in $\delta^{15} \mathrm{~N}$ with increasing body size, even though no attempts were made to consider the trophic position of the species, either estimated on bulk samples or, most importantly, on different ontogenetic stages of the species. Here, the first group included small-sized $D$. villosus specimens, the majority less than $10 \mathrm{mg}$ in weight. Transformed using the allometric equation proposed in Dobrzycka-Krahel et al. (2016), i.e., dry 
Table 2 Summary of published isotopic investigations on Dikerogammarus villosus in invaded systems

\begin{tabular}{|c|c|c|c|c|c|c|c|c|c|}
\hline Reference & & System & Location & Notes & Season & $\delta^{15} \mathrm{~N}$ & $\mathrm{~N}$ & $\delta^{15} \mathrm{~N}_{\text {baseline }}$ & $\overline{\mathrm{TP}}$ \\
\hline \multirow[t]{2}{*}{ van Riel et al. (2006) } & \multirow{2}{*}{$\begin{array}{l}\text { The } \\
\text { Netherlands }\end{array}$} & \multirow[t]{2}{*}{ River } & Waal & 1996-98 & Summer & 14.7 & 10 & & 2.6 \\
\hline & & & Waal & $2001-03$ & Summer & 10.6 & 33 & & 2.7 \\
\hline \multirow[t]{2}{*}{ Brauns et al. (2011) } & \multirow[t]{2}{*}{ Germany } & \multirow[t]{2}{*}{ Lake } & $\begin{array}{l}\text { Langer } \\
\text { See }\end{array}$ & Shore & Autumn & 9.2 & NA & & 2.3 \\
\hline & & & $\begin{array}{c}\text { Langer } \\
\text { See }\end{array}$ & $\begin{array}{l}\text { Retaining } \\
\text { wall }\end{array}$ & Autumn & 9.1 & NA & & 2.5 \\
\hline \multirow[t]{2}{*}{ Gergs et al. (2011) } & \multirow[t]{2}{*}{ Germany } & \multirow[t]{2}{*}{ Lake } & Constance & 2005 & Autumn & 15.1 & NA & $5.2(2)^{*}$ & 4.9 \\
\hline & & & Constance & 2006 & Autumn & 6.2 & NA & $6.1(2)^{\circ}$ & 2 \\
\hline $\begin{array}{l}\text { Bacela-Spychalska and Van } \\
\text { Der Velde (2013) }\end{array}$ & Poland & Lake & Zegrzynski & & NA & & 1 & & 3.7 \\
\hline Brandner et al. (2013) & Germany & River & Danube & & Summer & 11.6 & 6 & $2.8(2)^{*}$ & 2.8 \\
\hline \multirow[t]{2}{*}{ Koester and Gergs (2014) } & \multirow[t]{2}{*}{ Switzerland } & \multirow[t]{2}{*}{ River } & $\begin{array}{l}\text { Untere } \\
\text { Lorze }\end{array}$ & Hagendorn & Spring & 6.1 & 16 & $1.9(2)^{* *}$ & 1.9 \\
\hline & & & $\begin{array}{l}\text { Untere } \\
\text { Lorze }\end{array}$ & Maschwanden & Spring & 6.6 & 17 & $1.8(2)^{* *}$ & 1.9 \\
\hline \multirow[t]{4}{*}{ Rothhaupt et al. (2014) } & \multirow[t]{3}{*}{ Germany } & \multirow[t]{4}{*}{ Lake } & Constance & Site 1 & Summer & 8.5 & NA & $1.8(2) \#$ & 1.8 \\
\hline & & & Constance & Site 3 & Spring & 8.2 & NA & 1.7 (2)\# & 1.8 \\
\hline & & & Constance & Site4 & Summer & 8.2 & NA & $2.3(2) \#$ & 2.3 \\
\hline & Austria & & Constance & Site5 & Summer & 8.3 & NA & 1.7 (2)\# & 1.7 \\
\hline \multirow[t]{10}{*}{ Koester et al. (2016) } & \multirow[t]{10}{*}{ Germany } & \multirow[t]{7}{*}{ River } & Rhine & Site 1 & Autumn & 9.7 & 20 & $2.3(1) \S$ & 2.3 \\
\hline & & & Rhine & Site2 & Autumn & 10.6 & 20 & $1.9(1) \S$ & 1.9 \\
\hline & & & Rhine & Site3 & Autumn & 8.7 & 20 & $2.1(1) \S$ & 2.1 \\
\hline & & & Rhine & Site4 & Autumn & 9.8 & 20 & $2.1(1) \S$ & 2.1 \\
\hline & & & Rhine & Site5 & Autumn & 9.1 & 20 & $2.3(1) \S$ & 2.3 \\
\hline & & & Rhine & Site6 & Spring & 12.5 & 20 & $3.5(1) \S$ & 3.5 \\
\hline & & & Rhine & Site7 & Autumn & 9.0 & 20 & $2.2(1) \S$ & 2.2 \\
\hline & & \multirow[t]{2}{*}{ Lake } & Constance & Site8 & Autumn & 7.3 & 20 & $2.1(1) \S$ & 2.1 \\
\hline & & & Constance & Site9 & Autumn & 6.9 & 20 & $2.1(1) \S$ & 2.1 \\
\hline & & River & $\begin{array}{l}\text { Rhine } \\
\text { tributary }\end{array}$ & Site10 & Autumn & 12.0 & 20 & $1.9(1) \S$ & 1.9 \\
\hline Haubrock et al. (2019) & Italy & River & Arno & & Spring & 9.3 & 11 & & 2.1 \\
\hline
\end{tabular}

(B) D. villosus ontogenetic stages

\begin{tabular}{|c|c|c|c|c|c|c|c|c|c|c|}
\hline Reference & Country & System & Location & Notes & Season & $\delta^{15} \mathrm{~N}$ & $\mathrm{~N}$ & Size & $\delta^{15} \mathrm{~N}_{\text {baseline }}$ & $\overline{\mathrm{TP}}$ \\
\hline \multirow[t]{2}{*}{ van Riel et al. (2006) } & \multirow{2}{*}{$\begin{array}{l}\text { The } \\
\text { Netherlands }\end{array}$} & \multirow[t]{2}{*}{ River } & Waal & \multirow[t]{6}{*}{$2001-03$} & Summer & 11.3 & 5 & adults $>12 \mathrm{~mm}$ & & 2.9 \\
\hline & & & Waal & & Summer & 10.5 & 22 & juveniles & & 2.7 \\
\hline \multirow{4}{*}{$\begin{array}{l}\text { Hellmann et al. } \\
(2015)+\end{array}$} & \multirow[t]{4}{*}{ Germany } & \multirow[t]{2}{*}{ River } & Elbe & & Autumn & 11.0 & 17 & adults $>9 \mathrm{~mm}$ & & 1.9 \\
\hline & & & Elbe & & Autumn & 8.2 & $N A$ & juveniles & & 1.5 \\
\hline & & \multirow[t]{2}{*}{ River } & Rhine & & Autumn & 12.7 & 18 & adults $>9 \mathrm{~mm}$ & & 2.6 \\
\hline & & & Rhine & & Autumn & 11.7 & $N A$ & juveniles & & 2.4 \\
\hline \multirow[t]{5}{*}{ Koester et al. (2016) } & \multirow[t]{5}{*}{ Germany } & \multirow[t]{2}{*}{ River } & Rhine & \multirow[t]{2}{*}{ Site1 } & Autumn & 9.8 & 12 & adults $>9 \mathrm{~mm}$ & $2.3(1) \S$ & 2.3 \\
\hline & & & Rhine & & Autumn & 9.6 & 8 & juveniles & & 2.2 \\
\hline & & \multirow[t]{2}{*}{ River } & Rhine & Site2 & Autumn & 10.7 & 17 & adults $>9 \mathrm{~mm}$ & $1.9(1) \S$ & 2.0 \\
\hline & & & Rhine & & Autumn & 10.3 & 3 & juveniles & & 1.8 \\
\hline & & River & Rhine & Site3 & Autumn & 8.7 & 19 & adults $>9 \mathrm{~mm}$ & $2.1(1) \S$ & 2.1 \\
\hline
\end{tabular}


Table 2 continued

(B) D. villosus ontogenetic stages

\begin{tabular}{|c|c|c|c|c|c|c|c|c|c|c|}
\hline Reference & Country & System & Location & Notes & Season & $\delta^{15} \mathrm{~N}$ & $\mathrm{~N}$ & Size & $\delta^{15} \mathrm{~N}_{\text {baseline }}$ & $\overline{\mathrm{TP}}$ \\
\hline & & & Rhine & & Autumn & 7.5 & 1 & juveniles & & 1.6 \\
\hline & & River & Rhine & Site4 & Autumn & 9.9 & 3 & adults $>9 \mathrm{~mm}$ & $2.1(1) \S$ & 2.2 \\
\hline & & & Rhine & & Autumn & 9.7 & 17 & juveniles & & 2.1 \\
\hline & & River & Rhine & Site 5 & Autumn & 9.2 & 15 & adults $>9 \mathrm{~mm}$ & $2.3(1) \S$ & 2.4 \\
\hline & & & Rhine & & Autumn & 8.7 & 5 & juveniles & & 2.1 \\
\hline & & River & Rhine & Site6 & Spring & 12.6 & 20 & adults $>9 \mathrm{~mm}$ & $3.5(1) \S$ & 3.5 \\
\hline & & & Rhine & & Spring & 12.0 & 1 & juveniles & & 3.3 \\
\hline & & River & Rhine & Site7 & Autumn & 9.8 & 2 & adults $>9 \mathrm{~mm}$ & $2.2(1) \S$ & 2.6 \\
\hline & & & Rhine & & Autumn & 8.9 & 21 & juveniles & & 2.2 \\
\hline & & Lake & Constance & site8 & Autumn & 7.3 & 9 & adults $>9 \mathrm{~mm}$ & $2.1(1) \S$ & 2.2 \\
\hline & & & Constance & & Autumn & 7.2 & 12 & juveniles & & 2.1 \\
\hline & & Lake & Constance & Site9 & Autumn & 6.9 & 15 & adults $>9 \mathrm{~mm}$ & $2.1(1) \S$ & 2.1 \\
\hline & & & Constance & & Autumn & 6.9 & 5 & juveniles & & 2.1 \\
\hline & & River & Rhine tributary & Site10 & Autumn & 12.1 & 16 & adults $>9 \mathrm{~mm}$ & $1.9(1) \S$ & 1.9 \\
\hline & & & Rhine tributary & & Autumn & 11.6 & 4 & juveniles & & 1.7 \\
\hline
\end{tabular}

The first part of the table (A) includes references where D. villosus signatures were assessed on bulk samples, while the second (B) includes studies considering the ontogenetic stage of analyzed individuals (i.e., adult vs. juvenile). In part B the original, individually-resolved data by Koester et al. (2016) were grouped as juveniles and adults to compare them with data provided by van Riel et al. (2006) and Hellmann et al. (2015), taking the sizes provided in the latter publication as a reference. Additional information on the country, location, system, season, nitrogen isotopic signatures of $D$. villosus ( $\delta^{15} \mathrm{~N}=$ mean, $\mathrm{N}=$ number of analyzed samples) are reported. The table includes studies where the trophic position of D. villosus was not explicitly calculated; for the sake of comparison, a TP value (reported in bold) was estimated using the isotopic signatures of $D$. villosus and of a baseline species (*: Dreissena polymorpha ${ }^{\circ}=$ Centroptilum luteolum; **: Ancylus fluviatilis; \#: Limnomysis benedeni; $\$$ : periphyton; trophic level $\lambda$ provided in round brackets) using the equation provided in Vander Zanden and Rasmussen (1999; see text for further details)

+ : TP estimated using a $\Delta^{15} \mathrm{~N}=2.93$

weight $=0.0674 *$ total length ${ }^{2.6917}$ (expressed respectively in $\mathrm{mg}$ and $\mathrm{mm}$ ), this reference individual mass corresponds to a length of $6.4-6.5 \mathrm{~mm}$ roughly matching the lower size limit for adults (Devin et al. 2004b). Thus, the observed differences in isotopic signatures may to be due to an ontogenetic dietary shift. Growth in gammarid amphipods is essentially a continuous process, yet gonadal maturation generally induces a strong metabolic and physiological trade-off between investments in somatic or reproductive tissues. Accordingly, sexual maturity coincides with abrupt morphological changes and variations in energetic requirements, the latter in turn reflecting in ontogenetic diet shifts (Hartnoll 1982; Summers et al. 1997; Longo and Mancinelli 2014; Shi et al. 2020).

In the present study sexes were not determined; as male D. villosus are generally larger than females
(Devin et al. 2004b) it is possible that also sex may have contributed to the observed pattern, even though available information do not support this hypothesis (Maazouzi et al. 2009; Sahm et al. in press).

Small-sized killer shrimps showed a trophic position similar to that of E. veneris (2.57 vs. 2.41, respectively; Fig. 2). Dikerogammarus villosus juveniles are very efficient consumers of plant material before they reach maturity (Rewicz et al. 2017); similarly, E. veneris is predominantly a primary consumer; however, as generally observed for other gammarids in freshwater and brackish habitats, it can include animal items in the diet, especially in the winter season (Gophen 1979; see also Mancinelli 2012a, b). The similar trophic position, and the generally comparable carbon isotopic values, suggest that small-sized D. villosus may compete with $E$. 
veneris for trophic resources, a hypothesis supported also by their similar sizes $[E$. veneris reaches a maximum size of 10-12 mm (Gophen 1979; Herbst and Dimentman 1983)]. The sampling method used in this investigation allowed neither a quantitative analysis of the macrobenthic assemblage charactering the study site, nor a robust assessment of the relative densities of $D$. villosus and E. veneris in Lake Trasimeno; however, the disproportionality in the number of specimens collected for the two species is remarkable (Table 1). Echinogammarus veneris is the only native gammarid characterizing the littoral macrobenthic communities of Lake Trasimeno (VV.AA. 2015). The species was found at high abundance in 2015 and 2016 (Mancinelli et al. 2018; 2020); the extremely reduced occurrence recorded in 2018 at the same location (this study) coincides with the recent establishment of $D$. villosus and suggests that the latter may have played a negative impact on $E$. veneris abundance, as hypothesized for other native amphipods in other investigations (Muskó 1989; Bollache et al. 2004; Noordhuis et al. 2009). Besides representing an important food source for macroinvertebrates, fish, birds and amphibians, E. veneris also plays a major role in leaf detritus processing in lacustrine environments (Mancinelli et al. 2002, 2007). Significant variations in leaf detritus decomposition rates have been suggested to occur in freshwater systems after the arrival of $D$. villosus (Truhlar et al. 2014; Jourdan et al. 2016); thus, potential post-invasion variations in key functions of the benthic system of Lake Trasimeno deserve to be thoroughly addressed in future investigations.

In contrast with small-sized $D$. villosus, large-sized individuals showed a trophic position analogous to that of damselfly nymphs, and comparable with that of the hirudinean Erpobdella octoculata (Fig. 2). For odonates, in particular, the $\delta^{13} \mathrm{C}$ ranges indicate a potentially high overlap in the prey included in the diet and, in turn, competition or even intra-guild predation. Odonata larvae are generalist predators including a wide spectrum of invertebrate and vertebrate secondary consumers in their diet (Fischer 1964; Thompson 1978; Johnson 1991), while E. octoculata is a macrophagous opportunistic predator preying on a wide spectrum of benthic invertebrates, including chironomids, amphipods, insects, and conspecifics
(Dall 1983). Our results indicate that the trophic niche of large-sized D. villosus may overlap those of damselfly nymphs and, to a minor extent, of hirudineans, competing for food or even preying on both groups of native predators. While laboratory experiments indicate that the killer shrimp prey actively on hirudineans (Krisp and Maier 2005), information on odonate nymphs are less univocal: $D$. villosus is generally recognized to include them in its diet (Rewicz et al. 2014), yet laboratory trials showed low or negligible predation, a discrepancy likely to be related with the experimental design, as influenced by e.g., differences in sizes between prey and D. villosus individuals (Krisp and Maier 2005; Lipinskaya and Makarenko 2019 and literature cited).

Future investigations deserve to focus on the double, size-dependent role of $D$. villosus as an intra-guild competitor and predator for native primary consumers as well as for native invertebrate predators. It is apparent that a thorough analysis of the size structure of the invader' populations will be necessary to assess the relative prevalence of one role in respect with the other. To date, available information are relatively scant (but see Devin et al. 2004b), yet they indicate for the species an almost continuous reproduction, with juveniles present throughout the year, and a generally bi- or multi-modal size frequency distribution, as clearly suggested also by the present study (Fig. S1). Accordingly, to test how constant the functional duality highlighted here for the killer shrimp is, future studies need to include multiple seasonal samplings (i.e., temporal data), since the present investigation, as most of the isotopic studies carried out in the past (Table 1), focused only on a single season, thus providing only a snapshot of the trophic habits of the species.

The impact of omnivores on food webs and ecosystems is still under debate, due to the difficulties in predicting their ultimate functional effects on the general structure and dynamics of food webs (Wootton 2017). This difficulty is particularly challenging for invasive omnivores, as their direct and indirect effects on multiple trophic levels through resource consumption limit a robust assessment of their ecological impact on invaded communities (Gallardo et al. 2016; Tumolo and Flinn 2017). Even though limited in space and time, the individual-scale investigation carried out 
in the present study, and the results of the literature search, clearly indicated that at least two groups of specimens with distinct functional roles coexist as "ecological species" (sensu Polis 1984) within the same D. villosus population, reflecting potential simultaneous interactions with taxa located at different trophic levels. Obviously, the possibility for populations of the killer shrimp to adapt to local conditions, as generally assumed, is not ignored (as testified in Table 1 by the remarkable variability in trophic position estimations). Indeed, the present study adds an intraspecific dimension to the omnivorous nature of $D$. villosus, stressing the necessity to explicitly take into consideration its potentially multiple functions related to body size and, in turn, ontogenetic stage, for an ecologically meaningful assessment of the ecological impact of the gammarid in invaded communities (Médoc et al. 2018).

Acknowledgments Funding from the Italian Ministry of Instruction, University, and Research (Law n. 232 December $\left.11^{\text {th }}, 2016\right)$ to G.M. and from the project "Tratti bio-ecologici chiave in una specie invasiva: Procambarus clarkii" (Fundamental Research Funding), Department of Chemistry, Biology, and Biotechnology, University of Perugia to A.L. are acknowledged. All the authors provided their consent to participate to the study and to the publication of its results, and declare no competing interests. No ethical issues related with the use of animals in the performed analyses were involved. Original data are available upon request to the corresponding author. We thank Gianandrea La Porta for his advice on odonate nymphs identification; two anonymous reviewers made useful comments and suggestions that greatly improved an early version of the manuscript. This paper has been conceived and concluded during a sabbatical year of one the authors (GM) in the Department of Chemistry, Biology, and Biotechnology, University of Perugia (Italy), and is dedicated to Sofia Mancinelli, thy eternal summer shall not fade.

Funding Open access funding provided by Università del Salento within the CRUI-CARE Agreement.

Open Access This article is licensed under a Creative Commons Attribution 4.0 International License, which permits use, sharing, adaptation, distribution and reproduction in any medium or format, as long as you give appropriate credit to the original author(s) and the source, provide a link to the Creative Commons licence, and indicate if changes were made. The images or other third party material in this article are included in the article's Creative Commons licence, unless indicated otherwise in a credit line to the material. If material is not included in the article's Creative Commons licence and your intended use is not permitted by statutory regulation or exceeds the permitted use, you will need to obtain permission directly from the copyright holder. To view a copy of this licence, visit http://creativecommons.org/licenses/by/4.0/.

\section{References}

Anderson MJ (2005) PERMANOVA. Permutational multivariate analysis of variance. Department of Statistics, University of Auckland, Auckland.

Annabi A, Bardelli R, Vizzini S et al (2018) Baseline assessment of heavy metals content and trophic position of the invasive blue swimming crab Portunus segnis (Forskål, 1775) in the Gulf of Gabès (Tunisia). Mar Pollut Bull 136:454-463. https://doi.org/10.1016/j.marpolbul.2018.09.037

Bacela-Spychalska K, Van Der Velde G (2013) There is more than one 'killer shrimp': trophic positions and predatory abilities of invasive amphipods of Ponto-Caspian origin. Freshwat Biol 58:730-741. https://doi.org/10.1111/fwb. 12078

Bącela K, Grabowski M, Konopacka A (2008) Dikerogammarus villosus (Sowinsky 1894) (Crustacea, Amphipoda) enters vistula-the biggest river in the baltic basin. Aquat Invasions 3:95-98. https://doi.org/10.3391/ai.2008.3.1.16

Berezina N (2007) Food spectra and consumption rates of four amphipod species from the North-West of Russia. Fundam Appl Hydrobiol 168:317-326. https://doi.org/10.1127/ $1863-9135 / 2007 / 0168-0317$

Bij de Vaate A, Jazdzewski K, Ketelaars HAM et al (2002) Geographical patterns in range extension of Ponto-Caspian macroinvertebrate species in Europe. Can J Fish Aquat Sci 59:1159-1174. https://doi.org/10.1139/f02-098

Boeker C, Geist J (2015) Effects of invasive and indigenous amphipods on physico-chemical and microbial properties in freshwater substrates. Aquat Ecol 49:467-480. https:// doi.org/10.1007/s10452-015-9539-y

Bollache L, Devin S, Wattier R et al (2004) Rapid range extension of the Ponto-Caspian amphipod Dikerogammarus villosus in France: potential consequences. Arch Hydrobiol 160:57-66. https://doi.org/10.1127/0003-9136/ 2004/0160-0057

Brandner J, Auerswald K, Cerwenka AF et al (2013) Comparative feeding ecology of invasive Ponto-Caspian gobies. Hydrobiologia 703:113-131. https://doi.org/10.1007/ s10750-012-1349-9

Brauns M, Gücker B, Wagner C et al (2011) Human lakeshore development alters the structure and trophic basis of littoral food webs. J Appl Ecol 48:916-925. https://doi.org/10. 1111/j.1365-2664.2011.02007.x

Casellato S, Piana GL, Latella L et al (2006) Dikerogammarus villosus (Sowinsky, 1894) (Crustacea, Amphipoda, Gammaridae) for the first time in Italy. Ital J Zool 73:97-104. https://doi.org/10.1080/11250000500502293

Catasti M, Della Bella V, Di Giulio AM, et al. (2017) Un nuovo alieno in Umbria: il "gamberetto killer" del lago Trasimeno. Micron 37:16-19; available online at http://www. arpa.umbria.it/resources/docs/micron\%2037/MICRON3716.pdf.

Costantini ML, Mancinelli G, Mandrone S et al (2005) Combined effects of acidification and competition on the feeding preference of a freshwater macroinvertebrate, Asellus aquaticus (Crustacea: Isopoda): a laboratory experiment. Mar Freshw Res 56:997-1004. https://doi.org/ 10.1071/MF04272 
Dall PC (1983) The natural feeding and resource partitioning of Erpobdella octoculata L. and Erpobdella testacea SAV. in Lake Esrom. Denmark Int Rev ges Hydrobiol 68:473-500. https://doi.org/10.1002/iroh.19830680404

Development Core Team (2020) R: A language and environment for statistical computing. R Foundation for Statistical Computing, Vienna, Austria. http://www.R-project.org/.

Devin S, Beisel JN, Bachmann V et al (2001) Dikerogammarus villosus (Amphipoda: Gammaridae): another invasive species newly established in the Moselle river and French hydrosystems. Ann Limnol - Int J Lim 37:21-27. https:// doi.org/10.1051/limn/2001001

Devin S, Bollache L, Beisel J-N et al (2004a) Pigmentation polymorphism in the invasive amphipod Dikerogammarus villosus: some insights into its maintenance. J Zool 264:391-397.

https://doi.org/10.1017/ S0952836904005862

Devin S, Piscart C, Beisel J-N et al (2004b) Life history traits of the invader Dikerogammarus villosus (Crustacea: Amphipoda) in the Moselle River, France. Int Rev Hydrobiol 89:21-34. https://doi.org/10.1002/iroh.200310667

Dick JTA, Alexander ME, MacNeil C (2013) Natural born killers: an invasive amphipod is predatory throughout its life-history. Biol Invasions 15:309-313. https://doi.org/10. 1007/s10530-012-0287-9

Dobrzycka-Krahel A, Majkowski W, Melzer M (2016) Lengthweight relationships of Ponto-Caspian gammarids that have overcome the salinity barrier of the southern Baltic Sea coastal waters. Mar Freshwat Behav Physiol 49:407-413. https://doi.org/10.1080/10236244.2016. 1244948

Dörr AJM, Scoparo M, Caldaroni B et al (2020) Il Gambero Rosso della Louisiana e gli altri gamberi alloctoni in Umbria. In: Della Bella V (ed) Caratterizzazione e Diffusione delle Specie Aliene Acquatiche e di Ambienti Umidi in Umbria. ARPA Umbria, Perugia, pp 139-149

Dudgeon D, Arthington AH, Gessner MO et al (2006) Freshwater biodiversity: importance, threats, status and conservation challenges. Biol Rev 81:163-182. https://doi.org/ $10.1017 / \mathrm{s} 1464793105006950$

Eggers TO, Martens A (2001) Bestimmungsschlüssel der Süßwasser-Amphipoda (Crustacea) Deutschlands. Lauterbomia 42:1-68

Elton CS (1958) The ecology of invasions by animals and plants. Chapman \& Hall, New York

Emery-Butcher HE, Beatty SJ, Robson BJ (2020) The impacts of invasive ecosystem engineers in freshwaters: a review. Freshwat Biol 65:999-1015. https://doi.org/10.1111/fwb. 13479

Evangelista C, Olden JD, Lecerf A et al (2019) Scale-dependent patterns of intraspecific trait variations in two globally invasive species. Oecologia 189:1083-1094. https://doi. org/10.1007/s00442-019-04374-4

Fischer Z (1964) Some observations concerning the food consumption of dragonfly larvae of Erythromma najas Hans and Coenagrion hastulatum Charp. Pol Arch Hydrobiol 12:253-264

Gallardo B, Clavero M, Sánchez MI et al (2016) Global ecological impacts of invasive species in aquatic ecosystems. Glob Change Biol 22:151-163. https://doi.org/10.1111/ gcb. 13004
Gergs R, Grey J, Rothhaupt K-O (2011) Temporal variation in zebra mussel (Dreissena polymorpha) density structure the benthic food web and community composition on hard substrates in Lake Constance, Germany. Biol Invasions 13:2727-2738. https://doi.org/10.1007/s10530-011-99438

Gherardi F (2007) Biological invaders in inland waters: profiles, distribution, and threats. Springer Verlag, Dordrecht NL

Gophen M (1979) Population density, migration and food composition of Echinogammarus veneris (Heller) in Lake Kinneret (Israel). Hydrobiologia 66:99-104. https://doi. org/10.1007/BF00032038

Goretti G, Pallottini M, La Porta G et al (2020) Invertebrati acquatici alloctoni dell'Umbria. In: Della Bella V (ed) Caratterizzazione e Diffusione delle Specie Aliene Acquatiche e di Ambienti Umidi in Umbria. ARPA Umbria, Perugia, pp 123-136

Gusev AA, Guseva DO, Sudnik SA (2017) New record of the Ponto-Caspian gammarid Dikerogammarus villosus (Sowinsky 1894) in the southeastern part of the Baltic Sea (Kaliningrad oblast, Russia). Russ J Biol Invasions 8:218-225. https://doi.org/10.1134/S2075111717030055

Hartnoll RG (1982) Growth. In: Abele LG (ed) The biology of Crustacea. Academic Press, New York, pp 111-196

Haubrock PJ, Balzani P, Azzini M et al (2019) Shared histories of co-evolution may affect trophic interactions in a freshwater community dominated by alien species. Front Ecol Evol 7:1-16. https://doi.org/10.3389/fevo.2019.00355

Hellmann C, Worischka S, Mehler E et al (2015) The trophic function of Dikerogammarus villosus (Sowinsky, 1894) in invaded rivers: a case study in the Elbe and Rhine. Aquat Invasions 10:385-397. https://doi.org/10.3391/ai.2015.10. 4.03

Hellmann C, Schöll F, Worischka S et al (2017) River-specific effects of the invasive amphipod Dikerogammarus villosus (Crustacea: Amphipoda) on benthic communities. Biol Invasions 19:381-398. https://doi.org/10.1007/s10530016-1286-z

Herbst GN, Dimentman C (1983) Distributional patterns and habitat characteristics of Amphipoda (Crustacea) in the inland waters of Israel and Sinai. Hydrobiologia 98:17-24. https://doi.org/10.1007/BF00019247

Johnson DM (1991) Behavioral ecology of larval dragonflies and damselflies. Trends Ecol Evol 6:8-13. https://doi.org/ 10.1016/0169-5347(91)90140-S

Jourdan J, Westerwald B, Kiechle A et al (2016) Pronounced species turnover, but no functional equivalence in leaf consumption of invasive amphipods in the river Rhine. Biol Invasions 18:763-774. https://doi.org/10.1007/ s10530-015-1046-5

Kinzler W, Kley A, Mayer G et al (2008) Mutual predation between and cannibalism within several freshwater gammarids: Dikerogammarus villosus versus one native and three invasives. Aquat Ecol 43:457. https://doi.org/10. 1007/s10452-008-9206-7

Koester M, Gergs R (2014) No evidence for intraguild predation of Dikerogammarus villosus (Sowinsky 1894) at an invasion front in the Untere Lorze, Switzerland. Aquat Invasions 9:489-497. https://doi.org/10.3391/ai.2014.9.4.07

Koester M, Bayer B, Gergs R (2016) Is Dikerogammarus villosus (Crustacea, Gammaridae) a 'killer shrimp' in the 
River Rhine system? Hydrobiologia 768:299-313. https:// doi.org/10.1007/s10750-015-2558-9

Koester M, Schneider M, Hellmann C et al (2018) Is the invasive amphipod Dikerogammarus villosus the main factor structuring the benthic community across different types of water bodies in the River Rhine system? Limnologica 71:44-50. https://doi.org/10.1016/j.limno.2018.06.001

Konopacka A (2004) Invasive amphipods (Crustacea, Amphipoda) in Polish waters. Przegląd Zoologiczny 48:141-162

Krisp H, Maier G (2005) Consumption of macroinvertebrates by invasive and native gammarids: a comparison. J Limnol 64:55-59

Lang I, Evangelista C, Everts RM et al. (2020) Stable resource polymorphism along the benthic littoral-pelagic axis in an invasive crayfish. Ecolo Evolut, 10:2650-2660 https://doi. org/10.1002/ece3.6095

Lee F, Simon KS, Perry GLW (2018) Prey selectivity and ontogenetic diet shift of the globally invasive western mosquitofish (Gambusia affinis) in agriculturally impacted streams. Ecol Freshwat Fish 27:822-833. https://doi.org/ 10.1111/eff.12395

Liénart C, Garbaras A, Qvarfordt S, et al. (2020) (in press) Long-term changes in trophic ecology of blue mussels in a rapidly changing ecosystem. Limnol Oceanogr. https://doi.org/https://doi.org/10.1002/1no.11633

Limén H, van Overdijk CDA, MacIsaac HJ (2005) Food partitioning between the amphipods Echinogammarus ischnus, Gammarus fasciatus, and Hyalella azteca as revealed by stable isotopes. J Great Lakes Res 31:97-104. https://doi. org/10.1016/S0380-1330(05)70241-0

Lipinskaya TP, Makarenko AI (2019) Comparative analysis of predatory behavior of invasive alien Dikerogammarus villosus (Sowinsky 1894) and native Gammarus varsoviensis Jazdzewski, 1975 amphipods. Russ J Biol Invasions 10:349-357. https://doi.org/10.1134/S2075111719040052

Logan JM, Jardine TD, Miller TJ et al (2008) Lipid corrections in carbon and nitrogen stable isotope analyses: comparison of chemical extraction and modelling methods. J Anim Ecol 77:838-846. https://doi.org/10.1111/j.1365-2656.2008. 01394.x

Longo E, Mancinelli G (2014) Size at the onset of maturity (SOM) revealed in length-weight relationships of brackish amphipods and isopods: an information theory approach. Estuar Coast Shelf Sci 136:119-128. https://doi.org/10. 1016/j.ecss.2013.11.013

Lorenzoni M, Carosi A, Ghetti L (2020) La fauna ittica aliena in Umbria. In: Della Bella V (ed) Caratterizzazione e Diffusione delle Specie Aliene Acquatiche e di Ambienti Umidi in Umbria. ARPA Umbria, Perugia, pp 161-173

Ludovisi A, Gaino E (2010) Meteorological and water quality changes in Lake Trasimeno (Umbria, Italy) during the last fifty years. J Limnol 69:174-188

Maazouzi C, Masson G, Izquierdo MS et al (2007) Fatty acid composition of the amphipod Dikerogammarus villosus: feeding strategies and trophic links. Comp Biochem Physiol A Mol Integr Physiol 147:868-875. https://doi.org/ 10.1016/j.cbpa.2007.02.010

Maazouzi C, Piscart C, Pihan J-C et al (2009) Effect of habitatrelated resources on fatty acid composition and body weight of the invasive Dikerogammarus villosus in an artificial reservoir. Arch Hydrobiol 175:327-338. https:// doi.org/10.1127/1863-9135/2009/0175-0327

MacNeil C, Platvoet D, Dick JT et al (2010) The Ponto-Caspian "killer shrimp", Dikerogammarus villosus (Sowinsky 1894), invades the British Isles. Aquat Invasions 5:441-445. https://doi.org/10.3391/ai.2010.5.4.15

Mancinelli G (2012a) On the trophic ecology of Gammaridea (Crustacea: Amphipoda) in coastal waters: a Europeanscale analysis of stable isotopes data. Estuar Coast Shelf Sci 114:130-139

Mancinelli G (2012b) To bite, or not to bite? A quantitative comparison of foraging strategies among three brackish crustaceans feeding on leaf litters. Estuar Coast Shelf Sci 110:125-133

Mancinelli G, Vizzini S (2015) Assessing anthropogenic pressures on coastal marine ecosystems using stable CNS isotopes: state of the art, knowledge gaps, and communityscale perspectives. Estuar Coast Shelf Sci 156:195-204. https://doi.org/10.1016/j.ecss.2014.11.030

Mancinelli G, Costantini ML, Rossi L (2002) Cascading effects of predatory fish exclusion on the detritus-based food web of a lake littoral zone (Lake Vico, central Italy). Oecologia 133:402-411. https://doi.org/10.1007/s00442-002-1001-x

Mancinelli G, Costantini ML, Rossi L (2007) Top-down control of reed detritus processing in a lake littoral zone: experimental evidence of a seasonal compensation between fish and invertebrate predation. Int Rev Hydrobiol 92:117-134. https://doi.org/10.1002/iroh.200510962

Mancinelli G, Glamuzina B, Petrić M, et al. (2016) The trophic position of the Atlantic blue crab Callinectes sapidus Rathbun 1896 in the food web of Parila Lagoon (South Eastern Adriatic, Croatia): a first assessment using stable isotopes. Mediterr Mar Sci 17: 634-643. https://doi. org/10.12681/mms. 1724

Mancinelli G, Chainho P, Cilenti L et al (2017a) The Atlantic blue crab Callinectes sapidus in southern European coastal waters: distribution, impact and prospective invasion management strategies. Mar Pollut Bull 119:5-11. https:// doi.org/10.1016/j.marpolbul.2017.02.050

Mancinelli G, Guerra MT, Alujević K et al (2017b) Trophic flexibility of the Atlantic blue crab Callinectes sapidus in invaded coastal systems of the Apulia region (SE Italy): a stable isotope analysis. Estuar Coast Shelf Sci 198:421-431. https://doi.org/10.1016/j.ecss.2017.03.013

Mancinelli G, Papadia P, Ludovisi A et al (2018) Beyond the mean: a comparison of trace- and macroelement correlation profiles of two lacustrine populations of the crayfish Procambarus clarkii. Sci Total Environ 624:1455-1466. https://doi.org/10.1016/j.scitotenv.2017.12.106

Mancinelli G, Goretti E, Vizzini S et al (2020) Caratterizzazione funzionale delle specie aliene nella rete trofica del lago Trasimeno. In: Della Bella V (ed) Caratterizzazione e Diffusione delle Specie Aliene Acquatiche e di Ambienti Umidi in Umbria. ARPA Umbria, Perugia, pp 151-159

Marcus JH, Sutcliff DW, Willoughby LG (1978) Feeding and growth of Asellus aquaticus (Isopoda) on food items from the littoral of Windermere, including green leaves of Elodea canadensis. Freshwat Biol 8:505-519. https://doi.org/ 10.1111/j.1365-2427.1978.tb01473.x

Mayer G, Maier G, Maas A et al (2008) Mouthparts of the Ponto-Caspian invader Dikerogammarus Villosus 
(Amphipoda: Pontogammaridae). J Crust Biol 28:1-15. https://doi.org/10.1651/07-2867R.1

McCue MD, Javal M, Clusella-Trullas S et al (2020) Using stable isotope analysis to answer fundamental questions in invasion ecology: progress and prospects. Methods Ecol Evol 11:196-214. https://doi.org/10.1111/2041-210X. 13327

Médoc V, Thuillier L, Spataro T (2018) Opportunistic omnivory impairs our ability to predict invasive species impacts from functional response comparisons. Biol Invasions 20:1307-1319. https://doi.org/10.1007/s10530-017-16285

Minelli A (1979) Sanguisughe d'Italia. Catalogo orientativo e considerazioni biogeografiche. Biogeographia 6:279-313. https://doi.org/10.21426/B66110106

Muskó IB (1989) Amphipoda (Crustacea) in the littoral zone of Lake Balaton (Hungary). Qualitative and quantitative studies. Int Rev ges Hydrobiol 74:195-205. https://doi.org/ 10.1002/iroh.19890740206

Noordhuis R, van Schie J, Jaarsma N (2009) Colonization patterns and impacts of the invasive amphipods Chelicorophium curvispinum and Dikerogammarus villosus in the IJsselmeer area. Neth Biol Invasions 11:2067. https:// doi.org/10.1007/s10530-009-9487-3

Oksanen J, Blanchet FG, Friendly M, et al. (2019) Vegan: Community Ecology Package. R package version 2.5-6. http://cran.r-project.org/web/packages/vegan.

Pellan L, Médoc V, Renault D et al (2016) Feeding choice and predation pressure of two invasive gammarids, Gammarus tigrinus and Dikerogammarus villosus, under increasing temperature. Hydrobiologia 781:43-54. https://doi.org/10. 1007/s10750-015-2312-3

Pethybridge H, Choy CA, Logan JM, et al. (2018) A global meta-analysis of marine predator nitrogen stable isotopes: relationships between trophic structure and environmental conditions. Global Ecology and Biogeography 27:1043-1055. https://doi.org/10.1111/geb.12763

Polis GA (1984) Age structure component of niche width and intraspecific resource partitioning: can age groups function as ecological species? Am Nat 123:541-564

Post DM (2002) Using stable isotopes to estimate trophic position: models, methods, and assumptions. Ecology 83:703-718. https://doi.org/10.1890/00129658(2002)083[0703:usitet]2.0.co;2

Post DM, Layman CA, Arrington DA et al (2007) Getting to the fat of the matter: models, methods and assumptions for dealing with lipids in stable isotope analyses. Oecologia 152:179-189. https://doi.org/10.1007/s00442-006-0630-x

Quezada-Romegialli C, Jackson AL, Hayden B et al (2018) tRophicPosition, an $r$ package for the Bayesian estimation of trophic position from consumer stable isotope ratios. Methods Ecol Evol 9:1592-1599. https://doi.org/10.1111/ 2041-210X.13009

Quezada-Romegialli C, Jackson AL, Harrod C (2019) tRophicPosition: Bayesian Trophic Position Calculation with Stable Isotopes. $\mathrm{R}$ package version 0.7.7. http://cran.rproject.org/web/packages/tRophicPosition.

Rewicz T, Grabowski M, MacNeil C et al (2014) The profile of a "perfect" invader - the case of killer shrimp, Dikerogammarus villosus. Aquat Invasions 9:267-288. https://doi. org/10.3391/ai.2014.9.3.04
Rewicz T, Wattier R, Rigaud T et al (2017) The killer shrimp, Dikerogammarus villosus, invading European Alpine Lakes: a single main source but independent founder events with an overall loss of genetic diversity. Freshwat Biol 62:1036-1051. https://doi.org/10.1111/fwb.12923

Rothhaupt KO, Hanselmann AJ, Yohannes E (2014) Niche differentiation between sympatric alien aquatic crustaceans: an isotopic evidence. Basic Appl Ecol 15:453-463. https://doi.org/10.1016/j.baae.2014.07.002

Sahm R, Sünger E, Burmann L, et al. (2020) (in press) Compound-specific $\delta^{15} \mathrm{~N}$ analyses of amino acids for trophic level estimation from indigenous and invasive freshwater amphipods. Int Rev Hydrobiol. https://doi.org/10.1002/ iroh. 202002058

Shi L, Zhang X, Xiao W et al (2020) Ontogenetic diet change of hadal amphipods in the New Britain Trench revealed by fatty acid biomarker and stable isotope ratio. Deep Sea Res Part I Oceanogr Res Pap 160:103276. https://doi.org/10. 1016/j.dsr.2020.103276

Števove B, Kováč V (2016) Ontogenetic variations in the diet of two invasive gobies, Neogobius melanostomus (Pallas 1814) and Ponticola kessleri (Günther 1861), from the middle Danube (Slovakia) with notice on their potential impact on benthic invertebrate communities. Sci Total Environ 557-558:510-519. https://doi.org/10.1016/j. scitotenv.2016.03.048

Stock JH (1968) A revision of the European species of the Echinogammarus pungens-group (Crustacea, Amphipoda). Beaufortia 16:13-78

Strayer DL (2010) Alien species in fresh waters: ecological effects, interactions with other stressors, and prospects for the future. Freshwat Biol 55:152-174. https://doi.org/10. 1111/j.1365-2427.2009.02380.x

Summers RB, Delong MD, Thorp JH (1997) Ontogenetic and temporal shifts in the diet of the amphipod Gammarus fasciatus, in the Ohio River. Am Midl Nat 137:329-336. https://doi.org/10.2307/2426852

Taylor NG, Dunn AM (2017) Size matters: predation of fish eggs and larvae by native and invasive amphipods. Biol Invasions 19:89-107. https://doi.org/10.1007/s10530-0161265-4

Thompson D (1978) Prey size selection by larvae of the damselfly, Ischnura elegans (Odonata). J Anim Ecol 47:769-785

Tricarico E, Mazza G, Orioli G et al (2010) The killer shrimp, Dikerogammarus villosus (Sowinsky 1894), is spreading in Italy. Aquat Invasions 5:211-214. https://doi.org/10.3391/ ai.2010.5.2.14

Truhlar AM, Dodd JA, Aldridge DC (2014) Differential leaflitter processing by native (Gammarus pulex) and invasive (Dikerogammarus villosus) freshwater crustaceans under environmental extremes. Aquat Conserv Mar Freshwat Ecosyst 24:56-65. https://doi.org/10.1002/aqc.2375

Tumolo BB, Flinn MB (2017) Top-down effects of an invasive omnivore: detection in long-term monitoring of large-river reservoir chlorophyll-a. Oecologia 185:293-303. https:// doi.org/10.1007/s00442-017-3937-x

Van der Velde G, Nagelkerken I, Rajagopal S, et al. (2002) Invasions by Alien Species in Inland Freshwater Bodies in Western Europe: The Rhine Delta. In: Leppäkoski E, Gollasch S and Olenin S (eds) Invasive Aquatic Species of 
Europe. Distribution, Impacts and Management. Springer, Dordrecht NL, pp. 360-372

Vander Zanden MJ, Rasmussen JB (1999) Primary consumer $\delta^{13} \mathrm{C}$ and $\delta^{15} \mathrm{~N}$ and the trophic position of aquatic consumers. Ecology 80:1395-1404. https://doi.org/10.1890/ 0012-9658(1999)080[1395:pccana]2.0.co;2

van Riel MC, van der Velde G, Rajagopal S et al (2006) Trophic relationships in the Rhine food web during invasion and after establishment of the Ponto-Caspian invader Dikerogammarus villosus. Hydrobiologia 565:39-58. https://doi.org/10.1007/s10750-005-1904-8

VV.AA. (2015) Parco Regionale del Lago Trasimeno. Aspetti faunistici - Anfibi Rettili Pesci e Invertebrati. Regione Umbria - Servizio sistemi naturalistici e zootecnia. Available at: https://www.regione.umbria.it/documents/18/
2512711/Trasimeno_anfibi_rettili_pesci_inv_ott_15.pdf/ 359f3c6e-6c97-45b3-9cb9-5b6a57443f7e, last accessed 19/11/2020. pp. 55

VV.AA. (2020) Caratterizzazione e Diffusione delle Specie Aliene Acquatiche e di Ambienti Umidi in Umbria. ARPA Umbria, Perugia

Wootton KL (2017) Omnivory and stability in freshwater habitats: does theory match reality? Freshwat Biol 62:821-832. https://doi.org/10.1111/fwb.12908

Publisher's Note Springer Nature remains neutral with regard to jurisdictional claims in published maps and institutional affiliations. 